\title{
Assessing the Influence of Islamic Banks' Products' Quality Features on Customer Satisfaction in Nigeria
}

\author{
Bashir Baba ${ }^{1}$, Shafie Mohamed Zabri ${ }^{1}$, Ahmad Kaseri ${ }^{1}$ \\ ${ }^{1}$ Universiti Tun Hussein Onn Malaysia \\ 101 Parit Raja, Batu Pahat, Johor, 86400, Malaysia
}

DOI: $10.22178 /$ pos.35-4

JEL Classification: E50

Received 10.05.2018

Accepted 12.06.2018

Published online 17.06.2018

Corresponding Author:

Bashir Baba

bashirababa@gmail.com

(C) 2018 The Authors. This

article is licensed under a

Creative Commons

Attribution 4.0 License

(c) (1)

\begin{abstract}
Islamic banking is essential in today's competitive banking markets. Research in Islamic banking worldwide is focussed mainly on how distinct is Islamic banking from the conventional banking. This research aims at investigating the factors responsible for the satisfaction of Islamic banking customers. The study seeks to identify the Islamic banking products' quality features as they relate to customer satisfaction, to examine the level of customer satisfaction on Islamic banking products' in Nigeria. Three research questions and four hypotheses are formulated to guide the study. The methodology employed was a quantitative approach using a questionnaire as a tool for the collection of data. The respondents for this study are customers of Ja'iz bank Nigeria plc, the major Islamic bank in Nigeria. A convenient sampling technique was adopted to select the sample from the population (customers) of the Ja'iz bank plc. in Northern Nigeria. Hence self-administered questionnaire was chosen to gather the data. The data analysis was done using Statistical Package for Social Sciences (SPSS) version 23.0 and PLS-SEM 3.

The results show that perceived quality of the products significantly influences customers satisfaction. It also indicates that there is a higher correlation between the cost of using the products and the level of customer satisfaction, that is to say, customers are very cost conscious as they would like to use the products at a lower cost than the current obtainable one. The customers also showed a higher level of convenience in using the Islamic banking products, and compliance score indicated that the customers are satisfied that Islamic bank in Nigeria is Shari'ah compliant. This result serves as a signal to service providers in knowing what type of the products customers enjoyed using, and which of the products needed improvement so as to provide customers with what they want most, in order for the banks to keep the existing customers intact and lure more potential customers, and to the policymakers, regulators and other relevant stakeholders to play their respective roles toward sustaining Islamic banking industry in Nigeria.
\end{abstract}

Keywords: Islamic banking; products quality features; customer satisfaction; Nigeria.

\section{INTRODUCTION}

The banking establishment is an organizational set up that provides financial services to the general public, and it is considered in any given nation, as a vital sector in the economic setting [44]. The primary services offered by banks include all forms of financial transactions and safeguarding other valuables for customers [36]. There are mainly three (3) types of banks which include; (i)
The Central banks (ii) The Investment banks, and (iii) The retail banks. While the central banks oversee and regulate the activities of the retail banks, Investment banks deal with international and multi-national organisations. The retail or commercial banks conduct their operations directly to individuals and corporate institutions, and it is classified into two (2) categories; conventional and Islamic banks both of which serve almost the same purposes except that Islamic 
bank functions mainly in profit and loss sharing system, and also prohibition of interest charges (riba) in all its activities. Among the standard products dealt within the Islamic banks are Profit/loss sharing (Mudarabah), safekeeping (Wadi'ah), a joint venture (Musharakah), cost plus (Murabahah) and leasing (Ijarah) [7].

Prior to the inception of Ja'iz bank in Nigeria, the only operating system of banking was conventional which was built solely on the institution of interest (riba), it is a system whereby, a stated percentage of interest is charged on a debtor irrespective of the outcome of business ventures into, and that according to [12], led to various societal and economic tribulations etc.

Nigerian banking is a centre of concentrated banking sector where only five (5) largest banks control $62 \%$ of the total commercial banks' assets (National daily, October 2017), while the remaining 18 banks (Islamic bank inclusive) bagged only $38 \%$ of the market share as can be seen below (Figure 1):

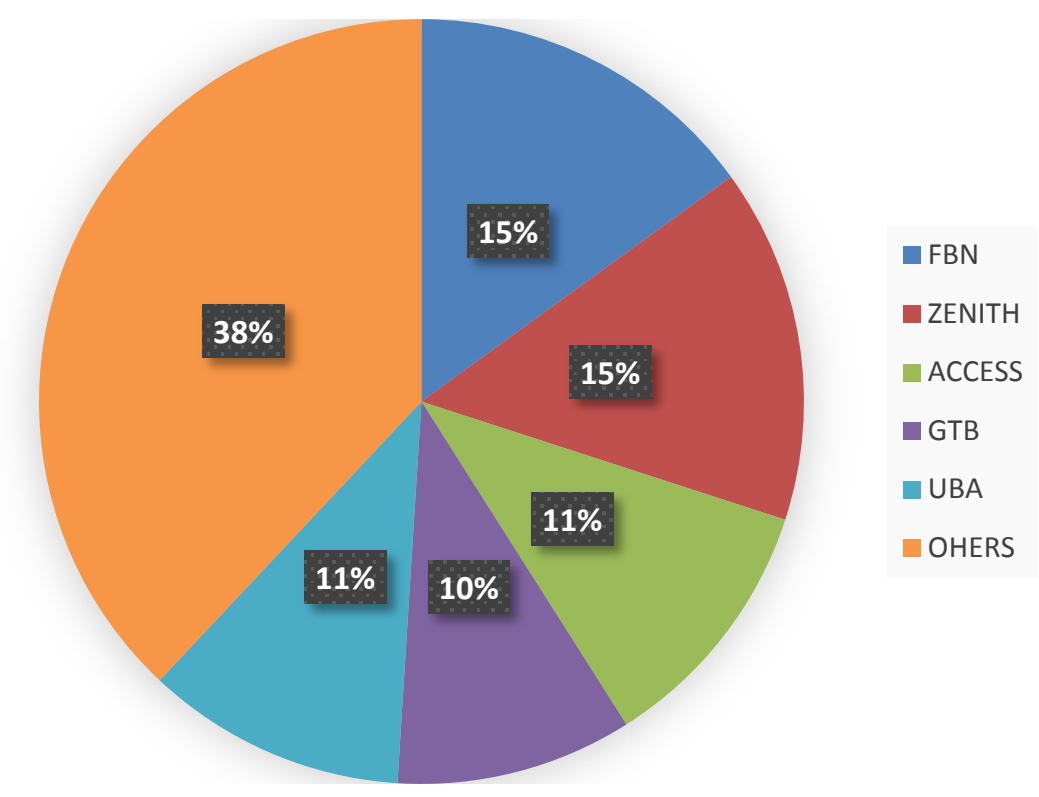

Figure 1 - The Nigerian banking sector market share, 2017 [18]

As shown in Figure 1, five banks maintained $62 \%$ of the total assets of the banks. First Bank of Nigeria has $15 \%$, Zenith bank Plc., $15 \%$, Access bank $11 \%$, GTB $10 \%$, UBA $11 \%$ and 18 others including the only Non-interest bank (Ja'iz bank Plc.) has only $38 \%$ of the total assets. This shows that there is a higher level of invariability in the proportion of the market share in the banking sector in Nigeria, hence the need to inquire what led to this invariability.

Attaining optimum customer satisfaction level and capturing a more significant marketing share is the dream of every business organisation, but achieving this particular goal has become a nightmare for almost all the organisations as a result of the dynamical nature of the taste of customers. This study aims at investigating the causal effects of customer satisfaction from the products features point of view. Identifying these factors can provide a smooth with the way for organisations/companies to attain higher satisfaction level from their customers, hence achieving their goals for the higher market share which will lead to holding existing customers and attracting new ones.

Nevertheless, the manner in which personal banking services are offered has experienced an intense overhaul as a result of the shift in the satisfaction of customers as each organisation has to offer qualitative products and services to attain maximum customer satisfaction and loyalty [33].

However, despite all efforts aimed at developing better services, customers remained not fully contented with the current services of the banks $[40,74]$.

From the inception of Islamic bank (Jaiz International Bank Plc.) in Nigeria, in the year 2012, substantial studies have been conducted. Some researchers were in support, while other researchers were against the operationalization of Jaiz bank in the country. The main debate surrounding the issuance of an operating license to the Ja'iz bank was seen as an attempt by the central bank of Nigeria towards favouritism and a step towards excluding non-muslims their banking 
right [82]. Some critiques were of the view that a bank cannot scale through without involving interest in its operation, while others argued and questioned the capacity of regulatory bodies in having enough rules that guide the activities of the Ja'iz bank alongside the rest of conventional banks in the country. Others still doubt the suitability of the environment for the services of Ja'iz bank as the society has been operating conventional system of banking for a long time, and lastly, is the issue of awareness from the citizens [81], and the larger portion of the unbanked public as a result of low level of financial literacy.

In an attempt to solve the problems above, researchers worked on some of the aspects, for instance on the issue of legality [64]; economic issue [78]; Acceptability [58]; their findings show that a larger portion of the respondents (98.1\%) known that ja'iz bank operates in Nigeria but only $35 \%$ of them had the knowledge of the varieties of products and services available in Ja'iz bank.

Research shows that, for new product/services to prosper in the marketplace, it is essential to know what factors influence its impact on the customers. From the review of the relevant literature, it was found that various factors can affect the intentions of customers towards banking services $[72,75]$.

While previous studies focused on the legality, acceptability, profitability, and opportunities of the Islamic banking in Nigeria, this research work centres on the factors influencing customer satisfaction on the quality features of the bank's products in Nigeria. Given the preceding, it is important to investigate the satisfaction level derivable from the patronage of the commonly used products of Islamic banking such as [2] a) Murabahah (Cost-Plus Sale Contract); b) Mudarabah (Silent Partnership); c) Ijarah (Lease) and d) Wadi'ah (Savings Account).

\section{LITERATURE REVIEW}

This chapter discusses previous research on Islamic banking and further concentrates on the factors influencing the degree of customer satisfaction on the performance of Islamic banking products in Nigeria. The overview of the previous research on the subject matter justifies the way research questions are to be answered. This study reviews its literature relevant to the subject matter from journals, articles, books and available reports from relevant bodies related to this work.

\section{Customer satisfaction}

The satisfaction of customers has been an essential part of every organisation as a result of an increase in the competition, and it is considered a crucial element of determining the competitiveness of banks [39]. In the words of [65], Satisfaction is the outcome of purchases which determines the choice that linked to the explicit buying decision, so, customers decision to continue or discontinue using the products or services previously consumed is determined by the satisfaction they derived from the previous usage. The popular way for the survival of any organisation depends on how it handles it is customers, hence constant evaluation of the level of the satisfaction of customers in a methodical manner is needed $[47,15]$. The main precept for successful competition in the market is customer satisfaction because it is the essential requirement for retaining customers to make profits. Customer satisfaction is vital in realising business lucrativeness, a higher share of the market and more earnings from investments [13].

Customer satisfaction stands as the total outcome of the internal state of minds of the customers on their involvement in using products or services. It is argued that each organisation should have customer satisfaction as its watchdog [68], and this could bring about a continuous buying habit that is needed for successful business activities in both short and long run. Authors [50], stressed that satisfaction is observed as the change between the expected performances (as perceived by the customers), and the thoughtful anticipation of needs. Looking at the relationship among the variables of customer satisfaction, [35], found a significant linkage amongst customer satisfaction, the quality of services and other constructs in Australian and Korean banks. From this submission it is clear that customer satisfaction is not a stand-alone concept, but an all-inclusive set of different players or indicators, which customers put into consideration to arrive at a conclusion on whether they are satisfied with not, customers do weigh what they obtained from using the products to what they really anticipated, once their experience matches their anticipation then, one can conclude that a satisfaction has been attained and vice-versa.

Customer satisfaction in the banking sector has been studied by numerous researchers using various item scales at different places, and many findings were reported. A study by [14], em- 
ployed the use of six item scale while [11], use one item scale to study "the conceptualization and measurement of service quality," and the nexus between customer satisfaction, service quality and intention to buy/use, and their findings were thus, the attainment of customer satisfaction was as a result of good quality of the services which has a substantial impact on the intention of the customers to continue with the patronage, and the study still found that the influence of service quality on intention to use was lesser than that of customer satisfaction though their method was seen as not sufficient because of the inclusion of only one item on the scale which if more items were to be used, the results might have been better and be more accepted by researchers like [56] who used five dimensions of customer satisfaction (core service or service products; human element of service delivery; systemization of service delivery (non-human element); tangibles of service (service scale) and social responsibility) to research for the interaction between customer satisfaction and service quality in the banking industry.

Several factors yield satisfaction of customers of which service quality is one of them. Authors [41] reported the benefit of attaining customer satisfaction from the service providers' perspective as higher profits, more coverage of market share, keeping customers tied to the products/services among others. Additionally, [38] in his study, found constant patronage, positive words of mouth, profits and loyalty as some of the benefit derivable as the result of achieving customer satisfaction. Equally important, the degree of satisfaction was tested in respect of perceived quality, and was found to be of straight and positively related as explored by [63]. In the same way, $[19,73]$, argued that, one of the ways the creation of customer satisfaction by banks can be attainable is by effective passage of information, capturing trust from the customers' side, and provision of quality products and services, harmonious conflict resolution system, and lastly, an inclusive improvement of customer care centre. The effect of customer satisfaction was surveyed in the Malaysian banking industry by [8], their study employed the use of SEM on 220 customers selected from 15 banks, and the study found a U-shaped connection between the perception of customers on satisfaction and positive word of mouth, and found customer satisfaction to be the chief cause of relationship quality in banking set up.

\section{Islamic banking}

A bank is an organisation that deals or accepts money from the savers in the form of deposit and disburse it to the borrowers in form advances and loans and performs other related functions concerning finance $[4,57]$. From the above definition of banking, it is clear that a bank is an intermediate organisation that performs a connecting role between the saving and the borrower's group. It performs the financial expertise services where it directs investors to where they invest their money profitably, banks do offer loans to borrowers to have higher returns for the money loaned, the borrower pays it in the form of interest, and it will be shared to the investors as returns on their investment. The different types of banks include commercial banks among others like merchant, development, mortgage and agriculture banks. A side of these is an Islamic bank that runs all the activities of banking, but it restricted its services within the confine of Islamic Law which prohibits the acceptances and distributions of interest (riba). Prior to the establishment of Islamic banking the world over, about 4 decades ago, the only existing banking system was the conventional one, which operates under a secular system, but the inception of the Islamic banking system brought about a rapid change in the global financial structure, which trimmed the monopolistic status enjoyed by the conventional banks, and created a competitive environment for the banks [67].

\section{Principles of Islamic banking}

The fundamental doctrines of the Islamic system of banking among others are; The profit and loss are sharing where the debtor and the financier distribute the gains, as well as the loss incurred from the business with the money obtained from the financier. Prohibition of unlawful businesses: it is not permissible to engage in the businesses that are made prohibited according to the Shariah, an example of such businesses includes, interest (riba), alcohol, pork, gambling, pornography etc. [46]. All these prohibitions were found from the two sources of Islamic Shariah law, either in the Glorious Qur'an or the Hadeeth of the prophet, and some of the reasons for the prohibition are among others, to keep away from Allah's fury as involving in riba contracts attracts it (Qur'an 2; 279), and also interest oppresses the borrowers and always dwindles the economy of the less privileged, abolishing alcohol so as to maintain human sense, etc. and Shariah law de- 
nounces both the givers and takers of interest [55]. All Islamic banks abide by these set of rules governing their operations, except where little differences can occur as a result of differences in the laws of operating countries, different environmental condition and needs for interaction with other conventional banks.

\section{Products of Islamic Banks}

Among the regular products utilised in the Islamic banking system are; benefit sharing (Mudarabah): Islamic banks offer funds and time deposits as venture accounts under the arrangement of Mudarabah, the investors of such accounts share benefits and misfortunes of the organisations under a settled-upon recipe [77]. The contributors in Mudarabah accounts are the providers of capital 'Rabb al-mal' who endow their assets to the bank, 'mudarib,' in the convention of western style venture system, subject to the dealings with just non-interest bearing instruments. The mudarib, going about as a cash director or specialist, contributes the cash and afterwards circulates the benefits and misfortunes by the settled upon contract.

The accompanying condition must be met; Profits to be shared must be relative to the assets added to the Mudarabah account, and these cannot be in bulk amounts or assured sums. The misfortune to the investor (patron of assets) cannot be more than the monetary value he deposited. Non-interest bearing demand deposits (financial records) [17]. Ordinary financial records in current business banks are non-interest bearing credits, and since Islamic banking establishments evade interest-fee based dealings, the greater part of them offer such demand deposits accounts. In a perfect world, Islamic banks ought not to charge any expense on financial records as they are allowed to utilize the investor's cash, subject to the hold prerequisites, if there are any, into procuring resources. In practice, however, this is not always the case, contingent upon the measure of the store, benefit charges get gathered to meet working expenses. The following are some of the products deals within Islamic banking system.

1. Joint-venture (Musharakah). This is a method of equity financing under the principles of Joint ventures where the bank engages in both the provision of finance as well as running the business by itself [52]. Musharakah is the first tool practices by Islamic banking in its product market; thus, in this scheme, the Islamic banking un- dertake the responsibility of the financier and that of the entrepreneur. This method is different form mudarabah in the sense that here, the bank plays a double role of supplying the money for the business and perform the complete task of managing the business while in the mudarabah system, two different parties are involved; the financier (separate from) the entrepreneur.

2. Mudarabah (Trust finance). This is a technique endorsed by the Islamic system of banking whereby, there is an act of partnership between two parties, a party provides the capital (financier) for the business while the other serves as an entrepreneur who manages the business. The profit or loss incurred by the business is shared between the two parties at the predetermined agreed-upon ratio. This method does not require setting up of a company, the Islamic bank can serve as the financier (Rabb-al-mal) on its own as well as on behalf of its clients, and it can also serve as the entrepreneur (Mudarib) as the case may be, to invest in different business arrangements.

3. Cost-plus financing (Murabahah). This is another instrument used by the Islamic banking system in which the bank buys a product on customer's behalf (based on the customer's request) and then resells it to the customer with added profit on the original amount of the said asset [3]. A clear example of this product is where the bank may buy an automobile at the cost of $\$ 20,000$ based on a client order, and after the bank possessed the item, it can now add up its profit and sell it to the client at a current price of $\$ 23,000$ to be paid in instalment in two years, or it can be paid in lump sum at the end the agreed loan term. This system is adopted by Islamic banks instead of charging interest from giving out raw loans to the customers (as can be seen in the practices of conventional banks), Islamic bank makes a profit from engaging in the business activities.

4. Leasing (Ijarah). Under this scheme, a customer can obtain a car (for example), under the principles of leasing (Ijarah), in this arrangement, the bank buys the car and lease it to the customer for agreed period, and the client pays a rental fee, and the customer assumes the total ownership of the leased item at the end of the leasing arrangement.

5. Safe-keeping (Wadi'ah). Under Wadi'ah arrangement, the bank guarantees the safety of the money and other valuables deposited by the clients for safekeeping, the bank charges a little 
amount for maintenance of items and custody of the funds kept and the client is always at will to withdraw his money or item deposited. This is the same with the savings and current accounts in the conventional banking system.

\section{Differences between Islamic and Conventional banks}

Islam abolishes all sorts of human and material exploitations, the existing conventional system of banking which is based on the principles of economics that money can create money is vehemently rejected by Islam, but Islam considers money as a factor of production whereby it can be ventured into a business for profit or loss, and the gain or loss incurred as the case may be must be borne by both the investor and the entrepreneur. Hence the need for profit and loss sharing system of banking based on the Islamic teachings.

The concept of brotherhood and cooperation is the foundational pillar Islamic banking was built upon, which considers a system of equity and risk sharing as the method of conducting business, and it serves all people from any religious affiliation. The central dissimilarities between Islamic and conventional banking systems are presented below (Table 1).

Table 1 - The central dissimilarities between Islamic and conventional banking systems

\begin{tabular}{|c|c|}
\hline Conventional banking & Islamic banking \\
\hline $\begin{array}{l}\text { The investment arrangement pays speculators } \\
\text { regardless of their actions, i.e. whether they act } \\
\text { responsibly or not. }\end{array}$ & $\begin{array}{l}\text { Islamic banks use Murabahah as a financing } \\
\text { strategy which involves the bank buying items } \\
\text { based on the customers' order and offer the item to } \\
\text { the customer at a value that incorporates a profit, it } \\
\text { is a system that shares benefit and loss through } \\
\text { (cost-plus financing), which is an agreement deal } \\
\text { between the bank and its client. }\end{array}$ \\
\hline $\begin{array}{l}\text { Lending is based on who has an underwriter and } \\
\text { securities. }\end{array}$ & $\begin{array}{l}\text { Lending is based on who needs it, and it does not } \\
\text { require collateral, it is built on trust. }\end{array}$ \\
\hline Principal partners are the investors. & $\begin{array}{l}\text { The main stakeholder is Allah; the objective is to } \\
\text { abide by order of Allah, while the partners are } \\
\text { users and the populace. Clients are accomplices, } \\
\text { and the choices are focused towards profiting the } \\
\text { society. }\end{array}$ \\
\hline Interest is charged on Lending. & $\begin{array}{l}\text { There is no involvement of interest (riba) because } \\
\text { Islamic system termed 'riba' as an unjustifiable } \\
\text { return, intrigue or extortion. }\end{array}$ \\
\hline $\begin{array}{l}\text { Supports arms enterprises and businesses that taint } \\
\text { the earth and escapade youngsters. }\end{array}$ & $\begin{array}{l}\text { Shari'ah law sets limits on business endeavours. } \\
\text { The law additionally prohibits the exchange of } \\
\text { liquor, tobacco, items that encompass pork, barrier } \\
\text { and weapon generation and particular diversion } \\
\text { and actions such as betting and explicit } \\
\text { entertainment (Chong and Liu, 2008). }\end{array}$ \\
\hline $\begin{array}{l}\text { Islamic ethics encourage a monetary arrangement } \\
\text { whereby all sorts of misuse are eliminated. Through an } \\
\text { instrument 'Mudarabah' (Trust financing), a benefit- } \\
\text { sharing mechanism between two bodies in which one } \\
\text { supplies the money and the other conducts the } \\
\text { managerial and entrepreneurial expertise. Benefits are } \\
\text { shared based on a foreordained proportion and losses } \\
\text { are borne by the supplier of the capital. }\end{array}$ & $\begin{array}{l}\text { The interest of the investors is always protected in } \\
\text { the made resolutions of the venture. }\end{array}$ \\
\hline $\begin{array}{l}\text { Islamic system has a concern about what and where } \\
\text { the money obtained is utilised. The Islamic system has } \\
\text { a say in the business accomplishments so that the } \\
\text { money can only be utilised in the shari'ah based } \\
\text { business activities. }\end{array}$ & $\begin{array}{l}\text { Scheduled for the individuals who have cash and } \\
\text { who could not care what it is utilised for. There is } \\
\text { no concern on where the money is to be invested } \\
\text { hence no provision of information on what aspect } \\
\text { of the business to venture the money into. }\end{array}$ \\
\hline
\end{tabular}




\section{Customer satisfaction in Islamic banking}

Research in services marketing has widely shown that customer satisfaction leads to customer loyalty [24, 49]. For instance [23], found that whether customers had replaced their insurance policies or allowed them to lapse depended on their prior satisfaction with the whole life coverage. Similarly, in their studies, [32, 54, $61]$, on a series of Islamic banks found that intentions to repurchase were positively related to core-service satisfaction. Another finding from a sample of Jordan Islamic bank customers showed that loyalty to the bank recorded a significant impact on customer satisfaction. While results from the work of [37], posited the proof of the positive impact of customer satisfaction from various service industries in both Islamic banks, and essential service on customer intention to put the facilities into use over and over, and endorse the services of Islamic banks to a colleague.

Pertaining the nexus among satisfaction, the Islamic bank and trust, trust has been regarded universally as an all-inclusive impression of the Islamic bank. There is a longstanding orientation in this variable since trust is also conceptualised as "a cumulative process that develops over the course of repeated, successful interactions" [62]. Satisfaction encounters are presumably to strengthen the trust of customers in The Islamic as "a cumulative process that develops over the course of repeated, successful interactions"[62]. An exceedingly satisfying experience with the Islamic bank might not only reassure the customer that his confidence in the provider of the service is rightly placed but also to augment it [54]. This argument was buttressed by an empirical study in marketing $[29,76]$, and in consumer behaviour works [30]. To the exclusive features of the Islamic banking arrangement, a customer acquires natural satisfaction in the general facets of the products and services offered by Islamic banks. Islamic banks, therefore, have a competitive advantage about enjoying customer confidence.

For instance, it is mainly agreed upon that a satisfied customer can engage a repeat purchase, and this results in a solid loyalty to the bank. As asserted by [26] and [69], customers who are satisfied are possibly involved in selling the excellent image of the company to others.

\section{Product quality}

The banking sector remains one of the areas that is being challenged with a total quality management theories and methodologies among service industries [9]. A customer oriented style to quality, espouse from such a thought, compels investigation on the needs of the customers [80]. This is strengthened for the reason that quality of service, in all-purpose is idiosyncratic, distinct from the quality of products, which can be measured empirically, and so a suitable way of measuring this feature is to evaluate the opinion of customers [48]. Measuring quality from this perspective has seen very slight attention in the banking sector at present. Reviewing the literature in this part shown that adopting a customer awareness approach to quality measurement in Islamic banking sector required a new framework which is more regular with each environment.

For quite a long time, competition has been a significant challenge faced by the firms who want to produce better quality products at a lower rate. To compete with any rival company, each company adopted an incorporated management idea, the attainment of which was demonstrated by the innovative firms like banking sector [20]. The tactical significance of quality management practices has been admitted by both managers and researchers [25]. Current opinions about the swap and collective models of competitive priorities make managers and researchers differentiate quality as the basic competitive variable, in the absence of which, the remaining priorities like flexibility, dependability, and cost are difficult to realize $[31,28,71]$.

Though quality management performance is studied in relevance literatures, the connection between quality practices built on quality dimensions and perceptions of customers permits an added study $[60,42]$. This study starts with a review of the quality dimension and perspectives, in the literature. Then, it establishes a framework and five plans to explore and analyse the relationships among quality dimensions, perspectives, and practices. Lastly, a discussion of its effects is presented.

\section{Quality dimensions and perspectives}

The definition of quality as given by the Cambridge international dictionary of English, the dimension is a depth and width of a particular thing in a given direction, especially its meas- 
urement, length, height, or a part or feature. Perspective is the method of considering something or a way of demonstrating in the art. If a thing is placed into view, it is compared with some other things so that it can be perfectly and justly umpired.

Quality is a multi-dimensional concept [31]. Thus, quality is seen inversely from a different point of view. Inherent multiple dimensions of quality gave rise to diverse standpoints about quality, which afterwards, affect quality practices. The outcome of quality practices, the extent to which all dimensions of quality needed by customers are accomplished, crafts the competitive ability of the company [43].

Every viewpoint makes a dissimilar expectation of how quality can be affected. Hence, it highlights several dimensions of quality. To address different quality dimensions similarly efficiently, managers need to recognize the boundary of each quality perspective since their quality perspective impressively confines their practices in which they might involve some quality dimensions with the separation of other dimensions, while these dimensions may be more applicable to competitive advantages [66].

\section{Conceptual framework}

Factors influencing customer satisfaction have been established in the literature, for instance, the work of $[34,32,10]$ indicated religion and economic factors as sole forces that derive customer satisfaction in Islamic banking sector. Authors [5] asserted that the majority of Islamic banking customers stressed religion as well as other factors like cost-benefit, service delivery, and location of patronising Islamic bank services. Also, [61] argued that customer patronage was determined by religion, bank name, bank image, provision quality service etcetera etc. Authors [21] on the other hand found in their study that age group, education level as the drivers for customer satisfaction in the United States of America, and his findings were in line with that of [51]. The main indicators of customer satisfaction were listed as a trust, commitment, communication, service quality and service handling [53].

The Figure 2 summarises indicators that were found to influence the level of customer satisfaction towards different underlying Islamic principles used in Islamic banking products.

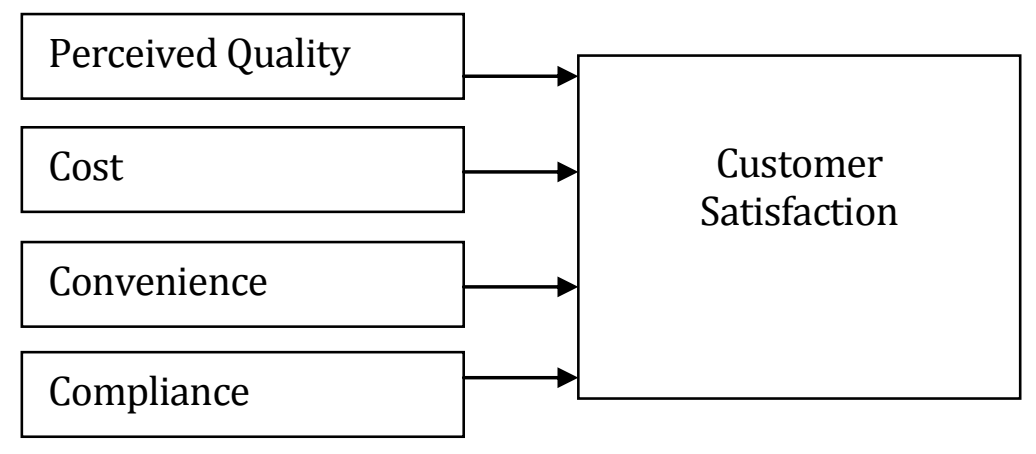

Figure 2 - Indicators that were found to influence the level of customer satisfaction towards different underlying Islamic principles used in Islamic banking products

The following hypotheses were formulated for this study:

H1: Perceived quality has an effect on customer satisfaction.

H2: Cost has an effect on customer satisfaction.

H3: Convenience has an effect on customer satisfaction.

H4: Compliance has an effect on customer satisfaction.
In this research, the main respondents are the customers of Ja'iz Islamic bank Nigeria Plc. The sample comprised the population within the Northeastern part of Nigeria which consists of Adamawa, Bauchi, Taraba, Borno, Yobe and Gombe states.

According to [22], sampling is about chosen (from within a statistical population), a subcategory to assess the features of the whole group. On the same note, [16] stated that the two main sampling methods in conducting quantitative re- 
search are: probability and nonprobability sampling. While in probability sampling every member of the population has a known, non-zero probability of selection and consequently is selected at random, in non-probability sampling, the probability of any member of the population being chosen is unknown. The advantage of probability sampling is that results can be generalised to the entire population, meaning the sample would be representative of the target population.

For the investigation of the relationship between the quality of the products features and customer satisfaction, the following hypotheses were developed using four constructs (perceived quality, Cost, Convenience and Compliance) as the independent variables while one construct (customer satisfaction as the dependent variable). A sample of 303 customers of Ja'iz bank Plc. completed the questionnaires. The survey consisted of $6 \mathrm{sec}-$ tions. The first section for the respondents' demography, the second part of the questionnaire consists the four products features, and the last section was on the satisfaction scale.

\section{RESULTS AND DISCUSSION}

It is recommended that upon identifying the underlying structure of the data through the EFA, a reliability analysis be conducted to further establish the reliability and validity of the constructs, and by extension the questionnaire $[45,58]$. The constructs reliability was tested using the Cronbach's Alpha method. The acceptable threshold for scale reliability is .70 and above, although .60 is also regarded as acceptable when the study is at its exploratory stage [58, 57]. The reported Scale's Cronbach's Alpha indicated that all the scales are reliable as they all meet up the threshold. The Customer satisfaction subscale reported the highest alpha value $(\alpha=.978)$ while Wadiah perceived quality reported the lowest alpha of value of $(\alpha=.748)$. The reported alpha value of the remaining scales also satisfied the recommended threshold of .70. In general, therefore; it could be concluded that the scales are reliable and could be used in measuring what they were intended to measure.

The demographic information shows that $64 \%$ of the respondents are Males while $36 \%$ are Females, and the age category depicted that $15.2 \%$ are from the younger age of 18 to 29, while $20.5 \%$ falls within the range of 30 to 39 years. Furthermore, $39.3 \%$ of the respondents are between 40 to 49 years and the eldest group (50 and above) form $25.1 \%$ of the total age distribution of the respondents, and this implies that considerable percentage of the working class form the majority of the customers of Ja'iz bank Nigeria Plc. Distribution of the customers by marital status indicated that $26.1 \%$ were singles, $63.0 \%$ belongs to the married class, while $10.9 \%$ were from the divorcees' class. The respondents' distribution by their level of education shows that $10.6 \%$ obtained secondary school certificates, $18.5 \%$ have Diploma/NCE, and $42.2 \%$ obtained their first degrees while $28.7 \%$ have postgraduate qualifications.

Monthly income of the respondents ranges from $15.2 \%$ for the low-income earners, $14.9 \%$ and $32.3 \%$ for the average and middle-income earners respectively, while the higher income earners class has $37.6 \%$. From the type of accounts held by the respondents, it is shown that $32.7 \%$ maintains a savings account, $39.9 \%$ are current account holders while corporate account holders formed $27.4 \%$. Responses on the products' usage reveal that $81.8 \%$ of the respondent use all the 3 products (Murabahah, Ijarah and Mudarabah) and $18.2 \%$ of them use only 2 (Murabahah and Ijarah) of the products, and lastly, the period engage in using the products show that $1.7 \%$ spent only 1 year, $13.5 \%$ spent 2 years, 19.1 have 3 years and $65.7 \%$ spent over 4 years using these products.

The overall PLS model is illustrated below (Figure 3).

As seen from the model above, the contribution of each of the constructs (by indicators), which shows that customers are more concerned with the cost of Ijarah (Ijarah $\rightarrow$ Cost at 0.699), then followed Wadi'ah cost also (wadia'h $\rightarrow$ Cost at 0.763) while Murabahah and Mudarabah scores higher (0.957 and 0.599) respectively in their perceived quality. The results show the satisfaction measure by each product towards customer satisfaction in percentage where Wadi'ah has $20 \%$, Ijarah $31 \%$, Murabahah $37 \%$ and Mudarabah has contributed to customer satisfaction by $12 \%$. 


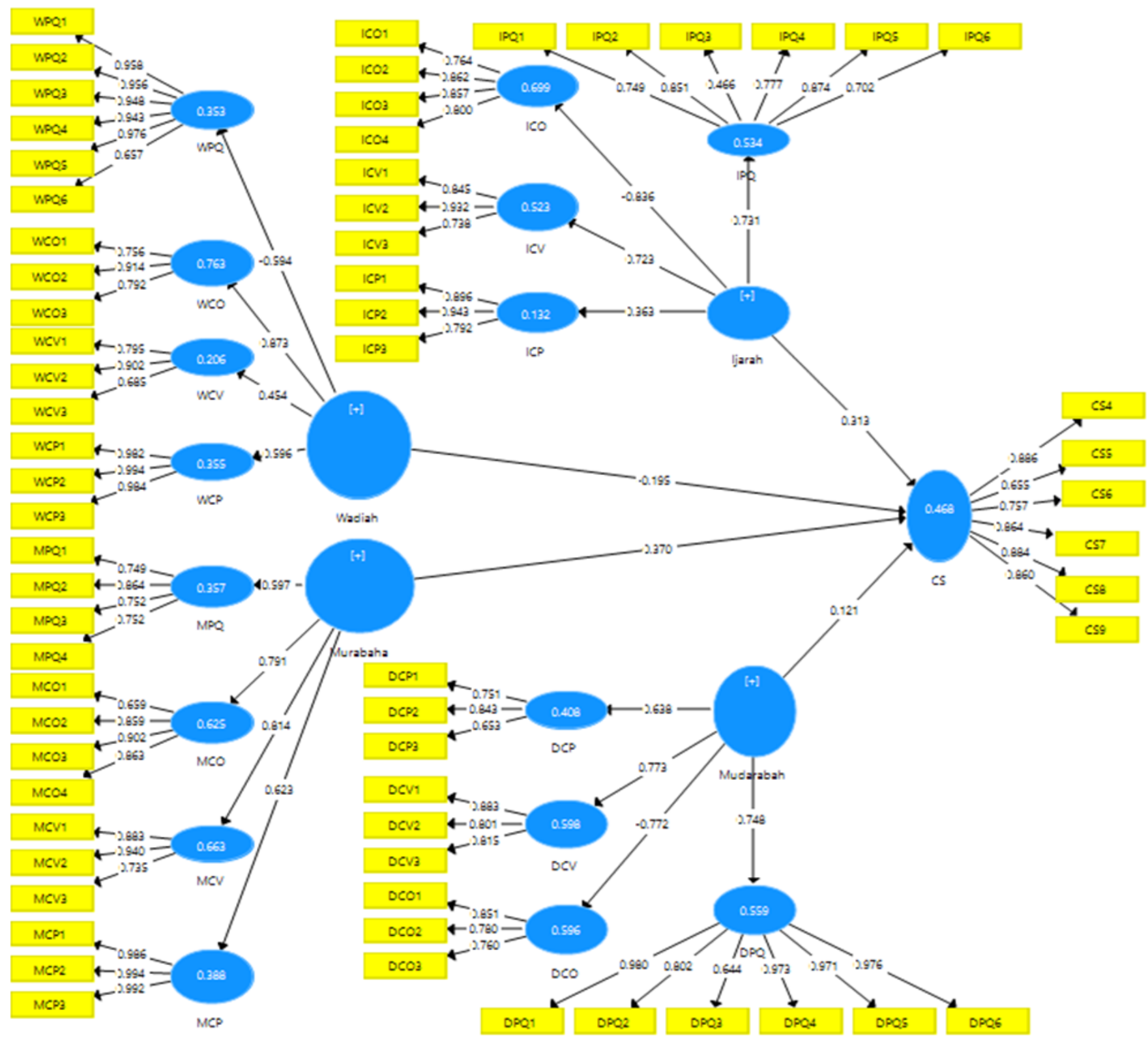

Figure 3 - The overall PLS model

\section{CONCLUSIONS}

The relationship between customer satisfaction and the quality of the products' features of Islamic bank is investigated in this study, 5 points Likert scale questionnaire was used to gather information from the respondents who are customers of the Ja'iz bank Nigeria Plc. The distribution of the respondents' demographic informa- tion was presented in the results section above. The quality Murabahah found to be the watchdog of the customers as it impacted most from the list of other products features. And lastly, the results presented the contribution of each of the products and its corresponding constructs and their respective contribution towards customer satisfaction.

\section{REFERENCES}

1. Rahman, Z. A. (2010). Contracts \& the products of Islamic banking. Malaysia: CERT Publications Sdn. Bhd.

2. Abdulsalam, A. (2011). Is Islamic banking relevant to Nigeria's economic development? Retrieved May 1, 2018, from http://www.wealthcity.in/is-islamic-banking-relevant-to-nigerias-economicdevelopment 
3. Ahmad, A., Rehman, K, \& Safwan, N. (2011). Comparative study of Islamic and conventional banking in Pakistan based on customer satisfaction. African Journal of Business Management, 5(5), 17681773.

4. Ahmad, A., Malik, M. I., \& Humayoun, A. A. (2010). Banking Developments in Pakistan: A Journey from Conventional to Islamic Banking. European Journal of Social Sciences, 17(1), 12-17.

5. Ahmad, N., \& Haron, S. (2002). Perceptions of Malaysian corporate customers towards Islamic banking products and services. International Journal of Islamic Financial Services, 3(4), 13-29.

6. Ajzen, I. (1991). The theory of planned behaviour. Organizational behavior and human decision processes, 50(2), 179-211.

7. Al-Deehani, T., EL-Sadi, H., \& Al-Deehani, M. (2015). The performance of Islamic banks and conventional banks before and during the economic downturn. Investment Management and Financial Innovation, 12(2), 238-250.

8. Amin, H., Abdul Rahman, A. R., Abdul Razak, D., \& Rizal, H. (2017). Consumer attitude and preference in the Islamic mortgage sector: a study of Malaysian consumers. Management Research Review, 40(1), 95-115. doi: 10.1108/mrr-07-2015-0159

9. Aquilani, B., Silvestri, C., Ruggieri, A., \& Gatti, C. (2017). A systematic literature review on total quality management critical success factors and the identification of new avenues of research. The TQM Journal, 29(1), 184-213. doi: 10.1108/TQM-01-2016-0003

10. Awan, H. M., \& Shahzad Bukhari, K. (2011). Customer's criteria for selecting an Islamic bank: evidence from Pakistan. Journal of Islamic Marketing, 2(1), 14-27. doi: 10.1108/17590831111115213

11. Bansal, H. S., \& Taylor, S. (2014). Investigating the Relationship Between Service Quality, Satisfaction and Switching Intentions. Proceedings of the 1997 Academy of Marketing Science (AMS) Annual Conference, 304-313. doi: 10.1007/978-3-319-13141-2_107

12. Abubakar, M., \& Bello, A. (2014). Challenges and Solutions to Islamic Banking System in a Pluralistic - Secular Country Like Nigeria. Journal of Islamic Economics Banking and Finance, 10(3), 184202. doi: $10.12816 / 0029048$

13. Ben Selma Mokni, R., \& Rachdi, H. (2014). Assessing the bank profitability in the MENA region. International Journal of Islamic and Middle Eastern Finance and Management, 7(3), 305-332. doi: 10.1108/imefm-03-2013-0031

14. Boohene, R., Agyapong, G. K. Q., \& Gonu, E. (2013). Factors Influencing the Retention of Customers of Ghana Commercial Bank within the Agona Swedru Municipality. International Journal of Marketing Studies, 5(4). doi: 10.5539/ijms.v5n4p82

15. Bouranta, N., Psomas, E. L., \& Pantouvakis, A. (2017). Identifying the critical determinants of TQM and their impact on company performance. The TQM Journal, 29(1), 147-166. doi: 10.1108/tqm11-2015-0142

16. Bryman, A., Bell, E., Mills A. J., \& Yue A. R. (2015). Business research methods. New York: Oxford University Press.

17. Castro, C. (2013). Islamic Banking. Procesos de Mercado, 10(1), 275.

18. CBN. (2017). Central Bank Supervision Annual Report, CBN yearly publication. Nigeria: (n. d.).

19. Chang, C.-S., Chen, S.-Y., \& Lan, Y.-T. (2013). Service quality, trust, and patient satisfaction in interpersonal-based medical service encounters. BMC Health Services Research, 13(1). doi: 10.1186/1472-6963-13-22

20. Chatzoglou, P., Chatzoudes, D., \& Kipraios, N. (2015). The impact of ISO 9000 certification on firms' financial performance. International Journal of Operations \& Production Management, 35(1), 145-174. doi: 10.1108/ijopm-07-2012-0387 
21. Cohen, D. A., Gan, C., Hwa, A., \& Chong, E. Y. (2006). Customer satisfaction: a study of bank customer retention in New Zealand. California: Lincoln University

22. Creswell, J. W. (2013). Research design: Qualitative, Quantitative, and Mixed Methods Approaches (4th ed.). London: Sage Publications, Incorporated.

23. Crosby, L. A., \& Stephens, N. (1987). Effects of Relationship Marketing on Satisfaction, Retention, and Prices in the Life Insurance Industry. Journal of Marketing Research, 24(4), 404. doi: $10.2307 / 3151388$

24. Dabholkar, P. A., Shepherd, C. D., \& Thorpe, D. I. (2000). A comprehensive framework for service quality: an investigation of critical conceptual and measurement issues through a longitudinal study. Journal of Retailing, 76(2), 139-173. doi: 10.1016/s0022-4359(00)00029-4

25. Dey, P. K., Bhattacharya, A., Ho, W., \& Clegg, B. (2015). Strategic supplier performance evaluation: A case-based action research of a UK manufacturing organisation. International Journal of Production Economics, 166, 192-214. doi: 10.1016/j.ijpe.2014.09.021

26. East, R. (1997). Consumer behavior: Advances and applications in marketing. London: Prentice Hall.

27. Field, A., Miles, J., \& Field, Z. (2012). Discovering statistics using R. London: Sage publications.

28. Flynn, B. B., \& Flynn, E. J. (2005). Synergies between supply chain management and quality management: emerging implications. International Journal of Production Research, 43(16), 34213436. doi: 10.1080/0020754050011807

29. Ganesan, S. (1994). Determinants of Long-Term Orientation in Buyer-Seller Relationships. Journal of Marketing, 58(2), 1. doi: 10.2307/1252265

30. Garbarino, E., \& Johnson, M. S. (1999). The Different Roles of Satisfaction, Trust, and Commitment in Customer Relationships. Journal of Marketing, 63(2), 70. doi: 10.2307/1251946

31. Garvin, D. A. (1993). Manufacturing Strategic Planning. California Management Review, 35(4), 85106. doi: $10.2307 / 41166756$

32. Gerrard, P., Barton Cunningham, J., \& Devlin, J. F. (2006). Why consumers are not using internet banking: a qualitative study. Journal of Services Marketing, 20(3), 160-168. doi: 10.1108/08876040610665616

33. Chen Goh, P. (2005). Intellectual capital performance of commercial banks in Malaysia. Journal of Intellectual Capital, 6(3), 385-396. doi: 10.1108/14691930510611120

34. Haron, S., \& Nursofiza Wan Azmi, W. (2008). Determinants of Islamic and conventional deposits in the Malaysian banking system. Managerial Finance, 34(9), 618-643. doi: 10.1108/03074350810890976

35. Hussain, R., Al Nasser, A., \& Hussain, Y. K. (2015). Service quality and customer satisfaction of a UAE-based airline: An empirical investigation. Journal of Air Transport Management, 42, 167175. doi: 10.1016/j.jairtraman.2014.10.001

36. Iqbal, M., \& Molyneux, P. (2006). Thirty years of Islamic banking: History, performance and prospects. London, UK: Palgrave Macmillan.

37. Jamal, A., \& Naser, K. (2003). Factors influencing customer satisfaction in the retail banking sector in Pakistan. International Journal of Commerce and Management, 13(2), 29-53. doi: 10.1108/eb047465

38. Kandampully, J., Zhang, T., \& Bilgihan, A. (2015). Customer loyalty: a review and future directions with a special focus on the hospitality industry. International Journal of Contemporary Hospitality Management, 27(3), 379-414. doi: 10.1108/ijchm-03-2014-0151

39. Karim, R., \& Chowdhury, A. T. (2014). Customer satisfaction on service quality in private commercial banking sector in Bangladesh. British Journal of Marketing Studies, 2(2), 1-11. 
40. Kassim, N., \& Asiah Abdullah, N. (2010). The effect of perceived service quality dimensions on customer satisfaction, trust, and loyalty in e-commerce settings. Asia Pacific Journal of Marketing and Logistics, 22(3), 351-371. doi: 10.1108/13555851011062269

41. Keiningham, T., Gupta, S., Aksoy, L., \& Buoye, A. (2014). The high price of customer satisfaction. MIT Sloan Management Review, 55(3), 37-46.

42. Keller, S., Korkmaz, G., Orr, M., Schroeder, A., \& Shipp, S. (2017). The Evolution of Data Quality: Understanding the Transdisciplinary Origins of Data Quality Concepts and Approaches. Annual Review of Statistics and Its Application, 4(1), 85-108. doi: 10.1146/annurev-statistics-060116054114

43. Kenyon, G. N., \& Sen, K. C. (2015). The Perception of Quality. doi: 10.1007/978-1-4471-6627-6

44. Kidwell, D. S., Blackwell, D. W., Sias, R. W., \& Whidbee, D. A. (2016). Financial institutions, markets, and money. Hoboken, NJ: John Wiley \& Sons.

45. Klyuvak, O., \& Skrynkovskyy, R. (2018). Diagnostics and Minimization of Business Risks and the State Customer in the System of Public e-Procurement. Path of Science, 4(1), 1022-1032. doi: $10.22178 /$ pos.30-4

46. Kumar, V., \& Shehryar, M. (2017). An Evaluation of Islamic Banking at Bank Muscat, Oman. Review of Integrative Business and Economics Research, 6(3), 254-262.

47. Lee, H. L., \& Chin, K. S. (2017). Development of a Systematic Model for Improving Software Quality in the Financial Service Organization. In Management Challenges in a Network Economy: Proceedings of the MakeLearn and TIIM International Conference 2017. Poland: ToKnowPress.

48. Leroi-Werelds, S., Streukens, S., Brady, M. K., \& Swinnen, G. (2013). Assessing the value of commonly used methods for measuring customer value: a multi-setting empirical study. Journal of the Academy of Marketing Science, 42(4), 430-451. doi: 10.1007/s11747-013-0363-4

49. Liljander, V., \& Mattsson, J. (2002). Impact of customer preconsumption mood on the evaluation of employee behavior in service encounters. Psychology and Marketing, 19(10), 837-860. doi: 10.1002/mar.10040

50. Lin, J., Hsiao, C.-T., Glen, R., Pai, J.-Y., \& Zeng, S.-H. (2012). Perceived service quality, perceived value, overall satisfaction and happiness of outlook for long-term care institution residents. Health Expectations, 17(3), 311-320. doi: 10.1111/j.1369-7625.2012.00769.x

51. Lopez, J., Kozloski Hart, L., \& Rampersad, A. (2007). Ethnicity and customer satisfaction in the financial services sector. Managing Service Quality: An International Journal, 17(3), 259-274. doi: 10.1108/09604520710744290

52. Malik, B. A., \& Khaki, G. N. (2015). Scope and Feasibility of Islamic Banking and Finance Model Kazakhstan \& Indian Perspective. The Journal of Central Asian Studies, 22(1), 83-98.

53. Massad, N., Heckman, R., \& Crowston, K. (2006). Customer Satisfaction with Electronic Service Encounters. International Journal of Electronic Commerce, 10(4), 73-104. doi: 10.2753/jec10864415100403

54. Metawa, S. A., \& Almossawi, M. (1998). Banking behavior of Islamic bank customers: perspectives and implications. International Journal of Bank Marketing, 16(7), 299-313. doi: 10.1108/02652329810246028

55. Mews, C. J., \& Abraham, I. (2006). Usury and Just Compensation: Religious and Financial Ethics in Historical Perspective. Journal of Business Ethics, 72(1), 1-15. doi: 10.1007/s10551-006-9151-0

56. Mittal, S., Gera, R., \& Batra, D. K. (2015). An evaluation of an integrated perspective of perceived service quality for retail banking services in India. International Journal of Bank Marketing, 33(3), 330-350. doi: 10.1108/ijbm-02-2014-0020

57. Moak, K. (2017). Developed Nations and the Economic Impact of Globalization. doi: 10.1007/978-3319-57903-0 
58. Muhammad, A. U., \& Gulani, M. G. (2013). Challenges facing the Acceptability of Islamic Banking in Nigeria. International Journal of Economic Development Research and Investment, 4(3), 31-41.

59. Mohammed, M. I., Sulaiman, N., \& Adamu, D. (2018). Dimensionality and Reliability of the Determinants of Reverse Mortgage Use Intention. Path of Science, 4(2), 1013-1023. doi: $10.22178 /$ pos.31-4

60. Naor, M., Goldstein, S. M., Linderman, K. W., \& Schroeder, R. G. (2008). The Role of Culture as Driver of Quality Management and Performance: Infrastructure Versus Core Quality Practices*. Decision Sciences, 39(4), 671-702. doi: 10.1111/j.1540-5915.2008.00208.x

61. Naser, K., Jamal, A., \& Al-Khatib, K. (1999). Islamic banking: a study of customer satisfaction and preferences in Jordan. International Journal of Bank Marketing, 17(3), 135-151. doi: 10.1108/02652329910269275

62. Nicholson, K. G., Colegate, A. E., Podda, A., Stephenson, I., Wood, J., Ypma, E., \& Zambon, M. C. (2001). Safety and antigenicity of non-adjuvanted and MF59-adjuvanted influenza A/Duck/Singapore/97 (H5N3) vaccine: a randomised trial of two potential vaccines against H5N1 influenza. The Lancet, 357(9272), 1937-1943. doi: 10.1016/s0140-6736(00)05066-2

63. Oh, H. J., Ozkaya, E., \& LaRose, R. (2014). How does online social networking enhance life satisfaction? The relationships among online supportive interaction, affect, perceived social support, sense of community, and life satisfaction. Computers in Human Behavior, 30, 69-78. doi: 10.1016/j.chb.2013.07.053

64. Olayemi, A. A. M. (2011). The Legality of Islamic Banking in Nigeria: A Critical Approach. SSRN Electronic Journal. doi: 10.2139/ssrn.1941010

65. Oliver, R. L. (2014). Satisfaction: A behavioral perspective on the consumer. doi: 10.4324/9781315700892

66. Peppard, J., \& Ward, J. (2016). The strategic management of information systems: Building a digital strategy. New York: John Wiley \& Sons.

67. P. Y. Lai, K., \& Samers, M. (2016). Conceptualizing Islamic banking and finance: a comparison of its development and governance in Malaysia and Singapore. The Pacific Review, 30(3), 405-424. doi: 10.1080/09512748.2016.1264455

68. Raza, S. A., Jawaid, S. T., \& Hassan, A. (2015). Internet banking and customer satisfaction in Pakistan. Qualitative Research in Financial Markets, 7(1), 24-36. doi: 10.1108/qrfm-09-20130027

69. Richins, M. L. (1983). Negative Word-of-Mouth by Dissatisfied Consumers: A Pilot Study. Journal of Marketing, 47(1), 68. doi: 10.2307/3203428

70. Ringle, C. M., Wende, S., \& Becker, J.-M. (2015). SmartPLS 3. Boenningstedt: SmartPLS GmbH. Retrieved May 1, 2018 from https://www.smartpls.com

71. Robinson, C. J., \& Malhotra, M. K. (2005). Defining the concept of supply chain quality management and its relevance to academic and industrial practice. International Journal of Production Economics, 96(3), 315-337. doi: 10.1016/j.ijpe.2004.06.055

72. Rosmain, T., Aliyu, A. A., Gafar, M., Abubakar, M. A., Lame, S. M., \& Takala, J. (2013). An empirical investigation of factors influencing customer service delivery of ATM users in Malaysia: Kano's model approach. Advances in Natural and Applied Sciences, 7(3), 269-276.

73. Rotich, H. K., \& Magara, E. (2015). Factors Influencing Customer Satisfaction as a Competitive Advantage in Commercial Banks in Kenya: A Case Study of Credit Bank Limited. The International Journal of Business \& Management, 3(5), 20.

74. Saeidipour, B., Ranjbar, H., \& Ranjbar, S. (2013). Adoption of Internetbanking. IOSR Journal of Business and Management, 11(2), 46-51. doi: 10.9790/487x-1124651 
75. Safeena, R., Date, H. \& Kammani, A. (2011). Internet Banking Adoption in an Emerging Economy: Indian Consumer's Perspective. International Arab Journal of e-Technology, 2(1), 56-64.

76. Selnes, F. (1998). Antecedents and consequences of trust and satisfaction in buyer-seller relationships. European Journal of Marketing, 32(3/4), 305-322. doi: 10.1108/03090569810204580

77. Siddiqui, S. A. (2008). An evaluation of research on monetary policy and stability of the Islamic economic system. In The 7th International Conference on Islamic Economics (Conference papers), 235-270.

78. Siyanbola, T. T. (2013). Islamic Banking as a Panacea for Economic Instability in Nigeria. Nigerian Chapter of Arabian Journal of Business and Management Review, 1(3), 69-89. doi: 10.12816/0003627

79. Souiden, N., \& Rani, M. (2015). Consumer attitudes and purchase intentions toward Islamic banks: the influence of religiosity. International Journal of Bank Marketing, 33(2), 143-161. doi: 10.1108/ijbm-10-2013-0115

80. Torku, P. (2015). A correlational study of manager leadership styles and service quality in Ghanaian banks (Doctoral dissertation). Phoenix: University of Phoenix.

81. Unegbu, V. E., \& Onuoha, U. D. (2013). Awareness and Use of Islamic Banking in Nigeria. Oman Chapter of Arabian Journal of Business and Management Review, 3(1), 57-76. doi: 10.12816/0002355

82. Yunusa, M., \& Nordin, N. B. (2015). Religious Challenges of Islamic Banking in Nigeria. International Journal of Academic Research in Business and Social Sciences, 5(4). doi: 10.6007/ijarbss/v5i4/1543 